\title{
Anti-angiogenic activity of carebastine: a plausible mechanism affecting airway
} remodelling

\author{
A. De Luisi*, G. Mangialardi" , R. Ria*, G. Acuto", D. Ribatti ${ }^{+}$and A. Vacca*
}

ABSTRACT: Ebastine is a well-known selective second-generation histamine $\mathrm{H}_{1}$ receptor antagonist, which is used for seasonal and perennial allergic rhinitis and chronic urticaria. Angiogenesis plays a crucial role in the development of airway inflammation and remodelling in allergic rhinitis and asthmatic patients, in whom, indeed, the mucosa displays increased vascularity and overexpression of vascular endothelial growth factor (VEGF). The aim of the present study was to evaluate the anti-angiogenic properties of carebastine, the active metabolite of ebastine.

The effects of carebastine on human umbilical vein endothelial cell (EC) (HUVEC) and human pulmonary artery EC (HPAEC) proliferation, migration and capillary-like tube formation were investigated in vitro, and in the chick embryo chorioallantoic membrane (CAM) assay in vivo. Moreover, the effect of carebastine on phosphorylation of the cell VEGF receptor fetal liver kinase-1, or VEGF receptor 2 (VEGFR-2), and Akt kinase (Akt) was evaluated by Western blotting.

Carebastine inhibited VEGF-induced HUVEC and HPAEC proliferation, migration and angiogenesis in a dose-dependent manner in vitro. Cell proliferation was inhibited by 42 and $64 \%$ in HUVECs and 62 and $75 \%$ in HPAECs upon exposure for 48 and $72 \mathrm{~h}$, respectively, to $20 \mu \mathrm{M}$ carebastine $(p \leqslant 0.03)$, and even more with $30 \mu \mathrm{M}$ carebastine. Cell migration was inhibited by 37 and $70 \%$ in HUVECs $(p \leqslant 0.03)$ and 60 and $78 \%$ in HPAECs $(p \leqslant 0.01)$ in the presence of 10 and $30 \mu \mathrm{M}$ carebastine, respectively. Carebastine $(20 \mu \mathrm{M})$ caused a significant reduction $(70-86 \%$; $\mathbf{p}<\mathbf{0 . 0 1}$ ) in topological parameters of the capillary network produced in vitro by both EC lines on a basement membrane extract. Carebastine (30 and $50 \mu \mathrm{M})$ inhibited the VEGF-induced angiogenesis in the CAM assay in vivo two- and three-fold, respectively $(p<0.001)$. Finally, both EC lines, on exposure to 10 and $20 \mu \mathrm{M}$ carebastine, showed a four- to six-fold reduction $(p \leqslant 0.01)$ in both VEGF- and $\mathrm{H}_{1}$ receptor-induced VEGFR-2 and Akt phosphorylation.

Overall, these data provide the first evidence regarding the anti-angiogenic activity of ebastine, and suggest its potential use as an anti-angiogenic molecule, besides its antihistaminic activity for the treatment of allergic diseases in which angiogenesis takes place.

KEYWORDS: Allergic diseases, anti-angiogenesis, asthma, carebastine, ebastine, endothelial cells

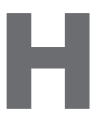
istamine $\mathrm{H}_{1}$ receptor antagonists are commonly used for symptomatic relief in the treatment of hypersensitive reactions, such as allergic rhinitis, rhinoconjunctivitis and urticaria. The ability of antihistamines to inhibit histamine release by mast cells is well known, whereas their additional properties, which contribute to their clinical efficacy, are incompletely understood. It has been reported that some antihistamines regulate the expression and/or release of cytokines, chemokines, adhesion molecules and other inflammatory mediators, and, consequently, that they inhibit the recruitment of inflammatory cells [1].

The anti-inflammatory effect of $\mathrm{H}_{1}$ receptor antagonists may involve a receptor-dependent mechanism via the inhibition of secretion of nuclear factor- $\kappa \mathrm{B}(\mathrm{NF}-\kappa \mathrm{B})$-dependent cytokines, such as vascular endothelial growth factor (VEGF), fibroblast growth factor (FGF) 2 and hepatocyte growth factor, or the inhibition of

\section{AFFILIATIONS}

${ }^{*}$ Dept of Internal Medicine and Clinical Oncology, Unit of Allergology and Clinical Immunology, Bari,

${ }^{+}$Dept of Human Anatomy and Histology, University of Bari Medical School, Bari,

Almirall, Milan, Italy.

\#Experimental Cardiovascular

Medicine, Bristol Heart Institute, University of Bristol, Bristol, UK

\section{CORRESPONDENCE}

A. Vacca

Dept of Internal Medicine and Clinical Oncology Unit of Allergology and Clinical Immunology Policlinico

Piazza Giulio Cesare 11

I-70124 Bari

Italy

E-mail: a.vacca@dimo.uniba.it

Received:

Nov 032008

Accepted after revision:

March 102009

First published online:

April 222009 
adhesion molecules [2-4]. Others have described receptorindependent mechanisms involving the release of preformed mediators, such as histamine and eosinophil proteins, as well as production of eicosanoid and oxygen free radicals [5-7].

Ebastine (4-diphenylmethoxy-1[3-(4-terbutyl-benzoyl)-propyl] piperidine) is a second-generation selective and potent $\mathrm{H}_{1}$ receptor antagonist with no anticholinergic or sedative effects, used for seasonal and perennial allergic rhinitis and chronic urticaria. Following oral administration, it is rapidly converted into its active metabolite, carebastine. It inhibits the secretion of interleukin (IL)-4, IL-5, IL- 6 and tumour necrosis factor- $\alpha$ by inflammatory cells [8].

Recent findings indicate that angiogenesis (new vessel formation) is involved in both the development of airway inflammation and pathophysiology of airway remodelling during the course of allergic rhinitis and asthma [9, 10]. Indeed, major structural and functional changes in the airway microcirculation include angiogenesis, increased blood flow and microvascular permeability, and oedema formation in the airway wall [11]. Increased expression of angiogenic molecules, such as VEGF, FGF-2 and angiogenin and their receptors, has been correlated with disease severity and accelerated decline in lung function [12-20]. Others have shown that bronchoalveolar lavage fluid (BALF) from asthmatic patients exhibits enhanced in vitro angiogenic activity and increased FGF-2 [21] and VEGF levels [22]; the BALF angiogenic activity is blocked by an antiVEGF antibody [22]. In addition, VEGF levels in the BALF of asthmatic patients were increased in proportion to the vessel number in the bronchial mucosa, which, indeed, showed intense VEGF, VEGF receptor (VEGFR)-1 and VEGFR-2 (or fetal liver kinase-1/kinase insert domain receptor) staining [20].

The direct contribution of VEGF to the allergic response in asthma has been proposed by LeE et al. [23], who generated lung-targeted $\mathrm{VEGF}_{165}$ transgenic mice and evaluated the role of VEGF in antigen-induced type-2 T-helper-cell-mediated inflammation. Overexpression of VEGF induced angiogenesis, oedema, vascular remodelling, leukocyte infiltration into the lung, collagen deposition, overexpression of IL-13 (which promotes the collagen deposition into the basement membrane), increased mucus production and smooth muscle cell hyperplasia.

The aim of the present study was to investigate the antiangiogenic activity of carebastine by using in vitro and in vivo assays. The former include human umbilical vein endothelial cell (EC) (HUVEC) and human pulmonary artery EC (HPAEC) proliferation, migration and capillary-like tube formation; the latter is the chick embryo chorioallantoic membrane (CAM) assay. Moreover, the effect of carebastine on cell VEGFR-2 and Akt kinase (Akt) phosphorylation was evaluated by Western blotting.

\section{MATERIALS AND METHODS}

\section{Cell culture and in vitro functional assays}

HUVECs were purchased from the American Type Culture Collection (ATCC; Manassas, VA, USA), and HPAECs were from Lonza (Walkersville, MD, USA). Both cell lines were cultured in EC basal medium EBM-2 supplemented with SingleQuots (Lonza) and 10\% fetal bovine serum (Gibco",
Invitrogen Corporation, Carlsbad, CA, USA) (complete medium) at $37^{\circ} \mathrm{C}$ in a $5 \% \mathrm{CO}_{2}$ atmosphere.

HUVEC and HPAEC proliferation was evaluated as previously

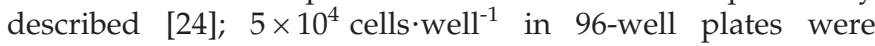
cultured for 24,48 and $72 \mathrm{~h}$ in starvation serum-free medium (SFM; negative control) or complete medium admixed with $10 \mathrm{ng} \cdot \mathrm{mL}^{-1}$ VEGF $_{165}$ (recombinant human $\mathrm{VEGF}_{165}$; SigmaAldrich, Milwaukee, WI, USA; positive control) or supplemented with $5-30 \mu \mathrm{M}$ carebastine (kindly supplied by Almirall, Barcelona, Spain) in five independent experiments performed in triplicate. Cells were counted using the 3-(4,5dimethylthiazol-2-yl)-2-5-diphenyl tetrazolium bromide (MTT) cell proliferation assay (ATCC), and expressed as mean \pm SD percentage of control. The EC number was also estimated using a slightly modified [24] crystal violet colorimetric method [25]. No aspecific cytotoxic effects (nuclear pyknosis, cytoplasmic vescicles and granules, round cell shape or cell detachment from supports) were seen in either HUVECs or HPAECs with carebastine, even at $30 \mu \mathrm{M}$.

The chemotactic assay was performed in Boyden microchambers, as previously described [26], towards SFM alone (negative control) or admixed with $10 \mathrm{ng} \cdot \mathrm{mL}^{-1} \mathrm{VEGF}_{165}$ alone (positive control) or together with the carebastine doses in five independent experiments performed in triplicate. After $4 \mathrm{~h}$, migrated cells were counted on five $1,000 \times$ magnification oilimmersion fields.membrane ${ }^{-1}$, and presented as mean $\pm S D$ percentage.

\section{In vitro angiogenesis assay}

HUVECs and HPAECs $\left(1 \times 10^{5}\right.$ cells $)$ were placed in 24-well plates pre-coated with Cultrex basement membrane extract (Trevigen, Inc., Gaithersburg, MD, USA; $400 \mu \mathrm{L} \cdot$ well $^{-1}$ ) in $1 \mathrm{~mL} \cdot$ well $^{-1}$ of SFM alone (negative control) or complete medium supplemented with $10 \mathrm{ng} \cdot \mathrm{mL}^{-1} \mathrm{VEGF}_{165}$ alone (positive control) or together with carebastine doses in five independent experiments performed in duplicate, and incubated at $37^{\circ} \mathrm{C}$ in a $5 \% \mathrm{CO}_{2}$ atmosphere. After an 18 -h incubation, tube and mesh formation were examined using a reverted phase-contrast microscope (Leitz DM IRB; Leica Microsystems, Wetzlar, Germany). Then the skeletonisation of the mesh was followed by measurement of its topological parameters, i.e. 1) number of areas, 2) vessel length, and 3) number of branching points, using computer image analysis as previously described [27], and presented as mean \pm SD percentage inhibition versus the positive control. Representative fields were photographed using a Leica D-Lux3 digital camera (Leica Camera, Solms, Germany).

\section{Chorioallantoic membrane assay}

The CAM assay was performed in fertilised White Leghorn chicken eggs incubated at $37^{\circ} \mathrm{C}$ at constant humidity as previously described [28]. On incubation day 3, a square window was opened in the shell and $2-3 \mathrm{~mL}$ albumen was removed in order to detach the CAM. On day 8 , the CAMs were implanted with $1-\mathrm{mm}^{3}$ sterilised gelatin sponges (Gelfoam Upjohn, Kalamazoo, MI, USA) loaded with $1 \mu \mathrm{L}$ medium alone (negative control) or added with $250 \mathrm{ng}$ VEGF $_{165}$ alone (positive control) or combined with 30 or $50 \mu \mathrm{M}$ carebastine in five independent experiments for each dose and control performed in duplicate. No embryo death 
was seen, even with $50 \mu \mathrm{M}$ carebastine. The angiogenic response was evaluated on day 12 as the number of vessels converging toward the sponge at $50 \times$ magnification, and photographed in ovo using an Olympus stereomicroscope (Olympus, Rozzano, Italy).

\section{Western blotting}

HUVECs and HPAECs were grown in six-well plate dishes in SFM containing $0.1 \%$ bovine serum albumin for $18-20 \mathrm{~h}$. Then the cells were exposed to $10 \mathrm{ng} \cdot \mathrm{mL}^{-1} \mathrm{VEGF}_{165}$ alone or combined with $30 \mu \mathrm{M}$ histamine (Sigma-Aldrich) followed by 10 and $20 \mu \mathrm{M}$ carebastine, and then lysed in a buffer containing $25 \mathrm{mM}$ tris(hydroxymethyl)aminomethane (Tris) $/ \mathrm{HCl}$, $150 \mathrm{mM} \mathrm{NaCl}, 1 \mathrm{mM}$ EDTA, 1\% Triton X-100, 0.1\% sodium dodecylsulfate (SDS), $1 \mathrm{mM} \mathrm{NaF}, 1 \mathrm{mM} \mathrm{Na} \mathrm{NO}_{4}$ and a protease inhibitor cocktail (Sigma-Aldrich). Total protein concentrations were determined by the Bradford method using the Bio-Rad Protein Assay (Bio-Rad, Hercules, CA, USA). Aliquots (30 $\mu \mathrm{g}$ protein) of the cell lysate were then separated by SDS-polyacrylamide gel electrophoresis (PAGE) using precast $4-12 \%$ NuPAGE Novex $_{\circledast}$ Bis-Tris gels (Invitrogen Corporation) under reducing conditions, electrotransferred to a polyvinylidene difluoride membrane (PerkinElmer Life Sciences, Inc., Boston, MA, USA) and incubated with the primary and secondary antibodies (antibodies directed against VEGFR-2, Akt and phospho-Akt (serine 473) were from Cell Signaling Technology (Danvers, MA, USA), against phosphoVEGFR-2 (tyrosine 1054) were from Abcam (Cambridge, UK), against $\beta$-actin, and goat immunoglobulin (Ig)G (horseradish peroxidase-conjugated) were from Santa Cruz Biotechnology (Santa Cruz, CA, USA), and against mouse and rabbit IgG (horseradish peroxidase-conjugated) were from Bio-Rad). Then bands were visualised by enhanced chemiluminescence (SuperSignal ${ }_{\circledast}$ West Pico substrate; Thermo Scientific, Inc., Waltham, MA, USA) using the Gel Logic 1500 Imaging System (Eastman Kodak Co., Rochester, NY, USA) and their intensity quantified using the Kodak Molecular Imaging Software, and expressed as mean \pm SD arbitrary optical density units based on five independent experiments.

For inhibition experiments, ECs were treated with $5 \mu \mathrm{g} \cdot \mathrm{mL}^{-1}$ anti-human VEGFR-2 neutralising monoclonal antibody (mAb) (R\&D Systems, Inc., Minneapolis, MN, USA) for $24 \mathrm{~h}$, and then exposed sequentially to $30 \mu \mathrm{M}$ histamine for $10 \mathrm{~min}$ and $10 \mu \mathrm{M}$ carebastine for $1 \mathrm{~h}$. In separate experiments, ECs were treated with $20 \mu \mathrm{M}$ mepyramine $\left(\mathrm{H}_{1}\right.$ receptor inhibitor; Sigma Chemical Co., St Louis, MO, USA) for $1 \mathrm{~h}$, and then exposed sequentially to $10 \mathrm{ng} \cdot \mathrm{mL}^{-1} \mathrm{VEGF}_{165}$ for $10 \mathrm{~min}$ and carebastine as above. The dose of mepyramine was chosen on the basis of a molar excess versus carebastine. Cells were then lysed and processed for Western blotting.

\section{RESULTS}

\section{Effect of carebastine on in vitro HUVEC and HPAEC proliferation, chemotaxis and angiogenesis}

The HUVEC and HPAEC proliferative response to VEGF 165 was significantly reduced by carebastine in a dose-dependent fashion, being maximal after a $72 \mathrm{~h}$ exposure to $30 \mu \mathrm{M}$ carebastine in both HUVECs (65\% reduction) and HPAECs ( $80 \%$ reduction) (fig. $1 \mathrm{a}$ and b). A significant lowering of cell proliferation was also achieved with $20 \mu \mathrm{M}$ carebastine after both $48 \mathrm{~h}$ (HUVECs $42 \%$ reduction and HPAECs $62 \%$ reduction; $\mathrm{p} \leqslant 0.03$ (two-way ANOVA)) and $72 \mathrm{~h}$ (HUVECs $64 \%$ reduction and $\mathrm{HPAEC}$ s $75 \%$ reduction; $\mathrm{p} \leqslant 0.01$ ), with median inhibitory concentrations of $28.7 \pm 6.9$ and $16.5 \pm 4.7 \mu \mathrm{M}$, respectively. These results were obtained using the MTT method and confirmed with the crystal violet colorimetric method (fig. 1 of online supplementary material). Carebastine exerted an inhibitory effect on the $\mathrm{VEGF}_{165}$-induced HUVEC and HPAEC migration in the chemotaxis assay (fig. 1c and d). The cell migration was inhibited by 12 and $45 \%, 37$ ( $<<0.03$ (one-way ANOVA $)$ ) and $60 \%(\mathrm{p}<0.01), 46$ and $68 \%(\mathrm{p}<0.01)$, and 70 and $78 \%$ in the presence of $5,10,20$ and $30 \mu \mathrm{M}$ carebastine, respectively.

Carebastine significantly inhibited HUVEC and HPAEC angiogenesis in vitro on the basement membrane extract. As shown in figure 2 , after an 18-h incubation $\mathrm{VEGF}_{165}$-exposed HUVECs produced a closely knit capillary network with thin, branching and anastomosing tubes linked through numerous junctions; mesh area counts were $31.2 \pm 7$, vessel length $6,814 \pm 618 \mu \mathrm{m}$ and branching point counts $37 \pm 5$. Exposure to carebastine at $1 \mu \mathrm{M}$, and even more at $20 \mu \mathrm{M}$, gave rise, in a dose-dependent manner, to a poorly organised plexus with few straight and disorganised tubes with scarce junctions; mesh area counts were $19.6 \pm 4.2(37 \%$ reduction) and $6.3 \pm 2.8$ (79\% reduction), vessel length $4,225 \pm 313$ (38\% reduction) and $1,135 \pm 126 \mu \mathrm{m}$ ( $83 \%$ reduction), and branching point counts $24 \pm 4$ (37\% reduction) and $11 \pm 3(70 \%$ reduction) respectively $(p \leqslant 0.01$ (paired t-test)). Overlapping changes were observed in the HPAEC capillary network following exposure to $20 \mu \mathrm{M}$ carebastine $(82 \%$ reduction in mesh areas, $86 \%$ reduction in vessel length and $75 \%$ reduction in branching points; data not shown).

\section{Effect of carebastine on in vivo angiogenesis in the CAM assay}

CAMs treated with sponges loaded with $\mathrm{VEGF}_{165}$ (positive control) were surrounded by allantoic vessels as newly formed capillaries converged radially towards the sponge in a spokewheel pattern ( $27 \pm 3$ vessels; fig. $3 b)$. No vascular response was detectable around the sponges loaded with vehicle alone

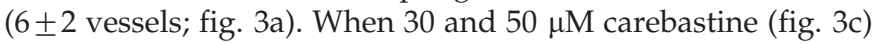
were added to $\mathrm{VEGF}_{165}$, a significant reduction in the angiogenic response was found $(14 \pm 2$ and $8 \pm 2$ vessels respectively; $\mathrm{p} \leqslant 0.01$ (paired $\mathrm{t}$-test).

\section{Effect of carebastine on VEGF-induced phosphorylation of VEGFR-2 and Akt}

In vivo experiments provided evidence that carebastine exerts an inhibitory effect on the VEGF-induced angiogenic response. In order to determine whether carebastine was able to inhibit VEGFR-2 and Akt phosphorylation, Western blotting experiments were performed in $\mathrm{VEGF}_{165}$-treated HUVECs. As shown in figure $4 \mathrm{a}, 10 \mu \mathrm{M}$ carebastine markedly blocked the VEGFdependent phosphorylation of VEGFR-2 (tyrosine 1054) $30 \mathrm{~min}$ after treatment, and the inhibitory effect was still detectable after a 24-h exposure to the drug. Moreover, the inhibition of receptor phosphorylation correlated with a marked decreased in the ability of VEGF to induce Akt phosphorylation under the same experimental conditions. As shown in figure $4 \mathrm{~b}$ and c, 10 and $20 \mu \mathrm{M}$ carebastine significantly 


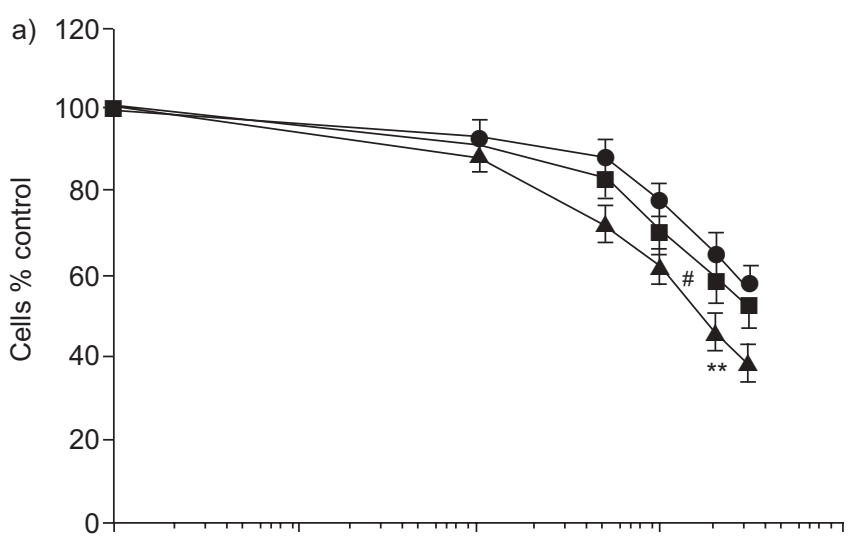

b)
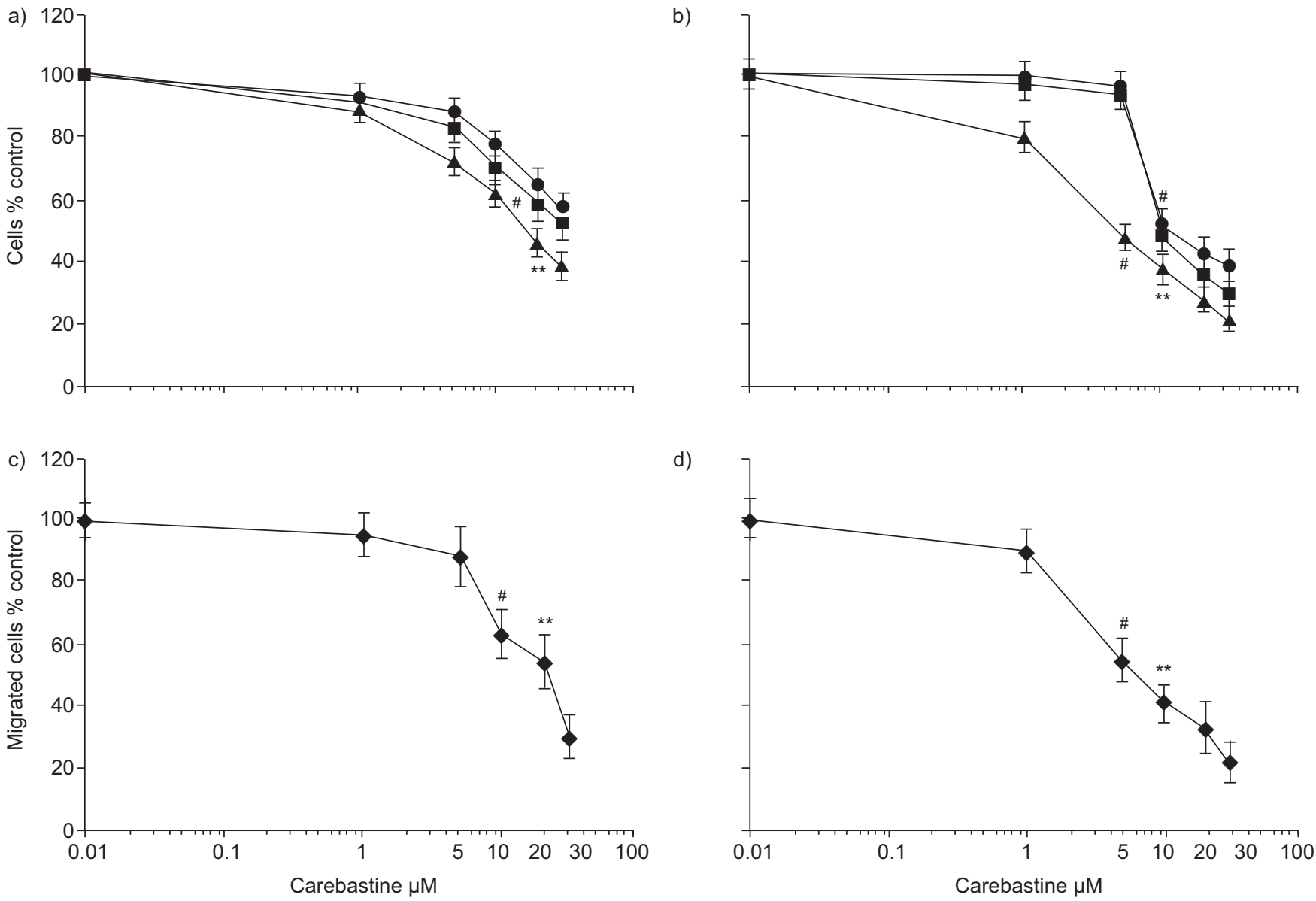

FIGURE 1. Effect of carebastine on the proliferation and migration of endothelial cells (ECs). Effects of different carebastine doses on vascular endothelial growth factor

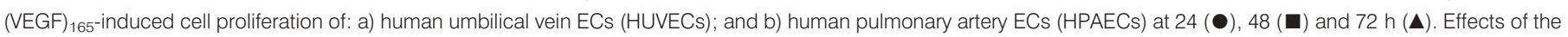
same doses on VEGF 165 -induced chemotaxis of: c) HUVECs; and d) HPAECs. Both cell types were plated on a collagen-coated polycarbonate membrane in a Boyden microchamber assay, and exposed to $\mathrm{VEGF}_{165}$ and carebastine at the indicated doses for $4 \mathrm{~h}$. Data are presented as mean $\pm \mathrm{SD}$ from five independent experiments performed in triplicate. ${ }^{*}: p<0.01 ;{ }^{*}: p<0.03$ (two-way ANOVA).

inhibited the VEGF-induced phosphorylation of both VEGFR-2 and Akt in a dose-dependent manner, and consequently blocked HUVEC survival.

\section{Effect of carebastine on the histamine signalling pathway mediated by the $H_{1}$ receptor in HUVECs and HPAECs}

In order to verify whether the $\mathrm{H}_{1}$ receptor was involved in the activation of VEGFR-2 and Akt, the effect of histamine treatment on protein phosphorylation was investigated. Western blotting analysis showed that stimulation of both ECs with $\mathrm{VEGF}_{165}$ followed by histamine produced a rapid (after a 10-min exposure) and sizeable increase in the phosphorylation of VEGFR-2 and Akt. When 10 and $20 \mu \mathrm{M}$ carebastine was added, it significantly blocked the histaminestimulated phosphorylation of both VEGFR-2 and Akt in HUVECs (fig. 5a, c and e) and HPAECs (fig. 5b, d and f), demonstrating that inhibition of the VEGFR-2 and Akt pathways by carebastine in both EC types is mediated by the blocking of $\mathrm{H}_{1}$ receptor activity.

In order to investigate whether carebastine was able to inhibit VEGFR-2 phosphorylation via simultaneous interference with the $\mathrm{H}_{1}$ receptor and VEGFR-2, inhibition experiments were performed with a neutralising anti-VEGFR-2 mAb and, separately, with mepyramine, an inhibitor of the $\mathrm{H}_{1}$ receptor. As shown in figure 6, blockade of VEGFR-2 produced marked inhibition of VEGFR-2 phosphorylation in histamine-stimulated HUVECs and HPAECs. In addition, slight inhibition was observed in VEGF $_{165}$-stimulated cells blocked in the $\mathrm{H}_{1}$ receptor with mepyramine and exposed to carebastine. The data suggest that the direct inhibitory activity of carebastine is mediated mostly by the $\mathrm{H}_{1}$ receptor and, to a lesser extent, by VEGFR-2.

\section{DISCUSSION}

Enhanced angiogenesis is involved in many aspects of tissue inflammation and remodelling, and contributes to abnormal airway function, including the increased mucosal reactivity to agents in allergic rhinitis and fixed airflow obstruction with progressive decline in lung function in asthma [9, 10]. The complex network between allergic inflammation and angiogenesis and the limited benefit of the classic therapeutic approaches to airway remodelling in inflammatory airway diseases, such as allergic rhinitis and asthma, have led to 

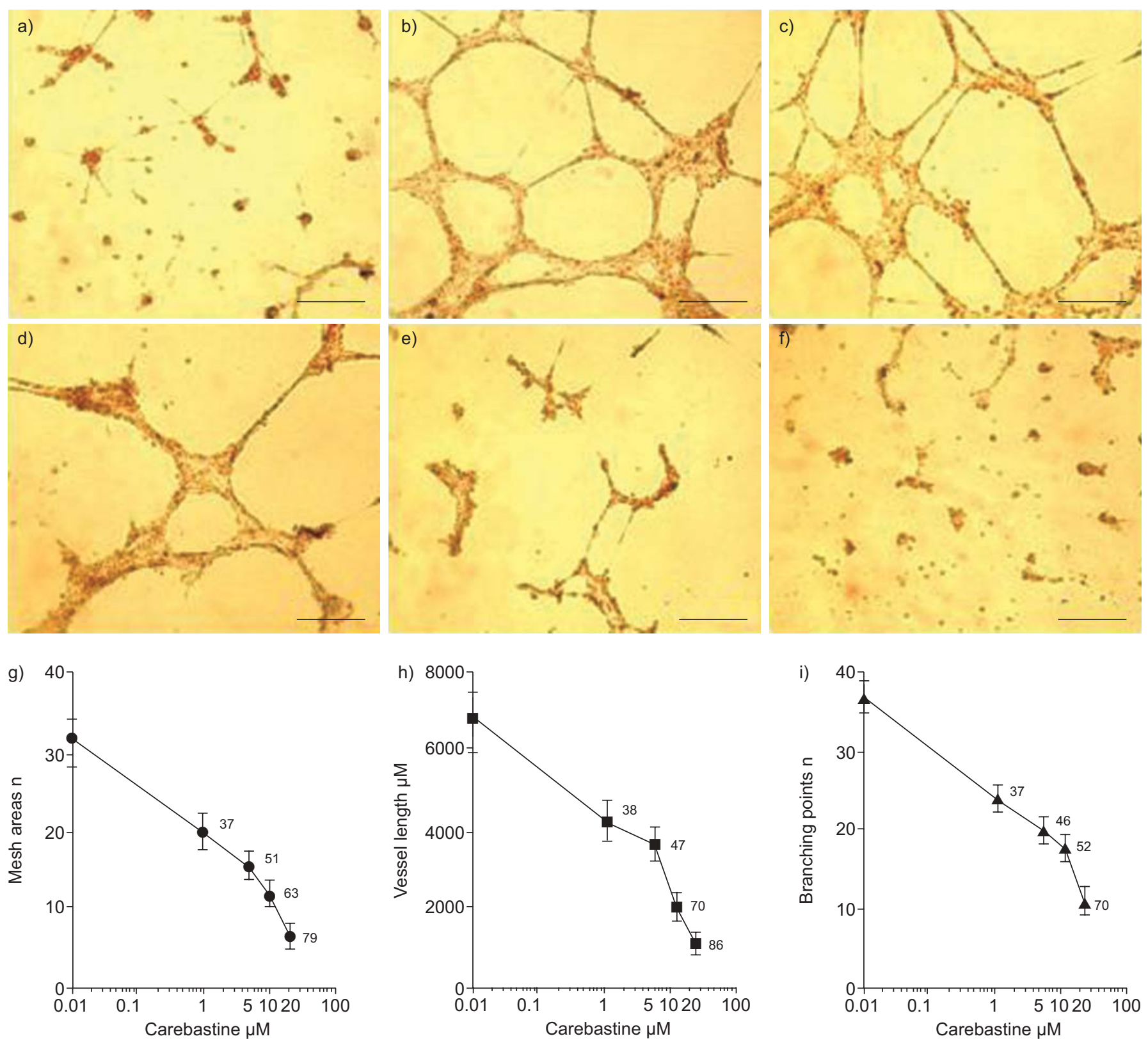

FIGURE 2. Effect of carebastine on in vitro angiogenesis. Human umbilical vein endothelial cells were seeded on Cultrex basement membrane extract (Trevigen, Inc., Gaithersburg, MD, USA) in: a) serum-free medium (SFM) alone; and b) SFM supplemented with vascular endothelial growth factor ${ }_{165}$ alone; and together with: $\mathrm{c}$ ) $1 \mu \mathrm{M}$ carebastine; d) $5 \mu \mathrm{M}$ carebastine; e) $10 \mu \mathrm{M}$ carebastine; and f) $20 \mu \mathrm{M}$ carebastine. Tube formation was observed periodically using a phase-contrast microscope and photomicrographs were taken after an 18-h incubation. One representative experiment is shown. Skeletonisation of the mesh was followed by measurement of its topological parameters: g) mesh areas; h) vessel length; and i) branching points. Data are presented as mean \pm SD from five independent experiments performed in duplicate. Numbers indicate percentage inhibition. Scale bars $=15 \mu \mathrm{m}$.

consideration of the use of angiogenesis inhibitors to control inflammation, angiogenesis and remodelling in allergic disorders.

Herein, it has been demonstrated for the first time that ebastine, a well-known selective and potent $\mathrm{H}_{1}$ receptor antagonist widely used for seasonal and perennial allergic rhinitis and chronic urticaria, exhibits potent anti-angiogenic activity, as demonstrated by in vitro and in vivo assays. Experiments performed using the in vivo CAM assay have provided evidence that carebastine (the active metabolite) exerts an inhibitory effect on the VEGF-induced angiogenic response. These results were confirmed by Western blotting, indicating that the inhibition of VEGFR-2 phosphorylation by carebastine interferes with the signalling pathways triggered by VEGF. Moreover, the inhibition of receptor phosphorylation correlated with a marked decrease in the ability of VEGF to induce Akt activation under the same experimental conditions. Finally, carebastine was also able to significantly block histamine-stimulated phosphorylation of both VEGFR-2 and 

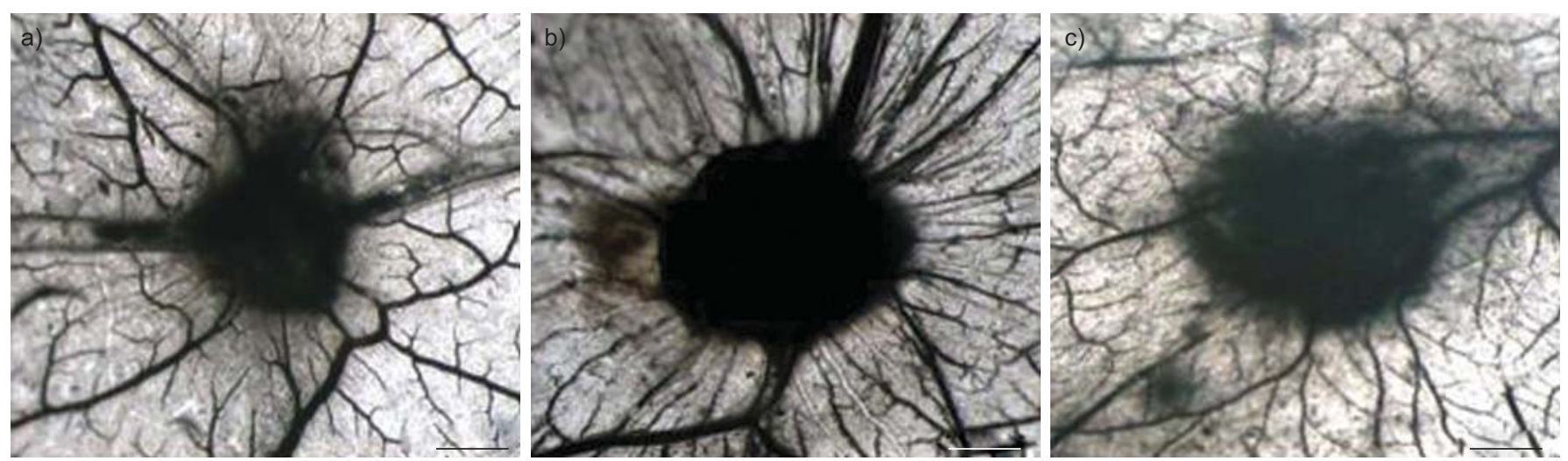

FIGURE 3. Effect of carebastine on in vivo angiogenesis (chorioallantoic membrane (CAM) assay). CAMs were implanted with sponges loaded with: a) serum-free medium (SFM) alone; b) SFM supplemented with vascular endothelial growth factor (VEGF) ${ }_{165}$ alone; and c) with $50 \mu \mathrm{M}$ carebastine. VEGF induced a strong angiogenic response in the form of newly formed capillary vessels, whereas no vascular response was detectable around the sponges loaded with SFM alone. Carebastine inhibited the $V_{E G F}{ }_{165}$-induced angiogenic response. One representative experiment of five independent experiments performed in duplicate for the carebastine dose and controls are shown. Scale bars $=1 \mathrm{~mm}$.

a)

\section{Total VEGFR-2}

pVEGFR-2

pAkt

Total Akt

$\beta$-actin

c) 800

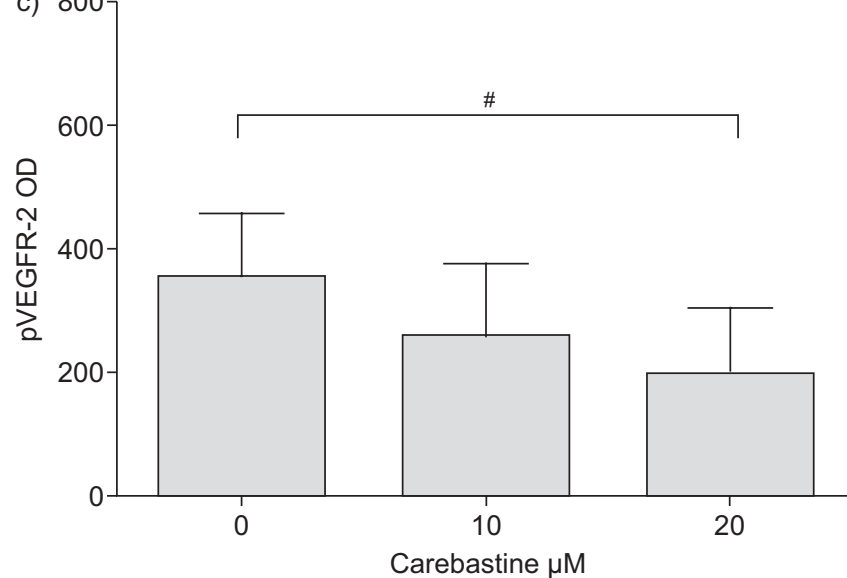

b)

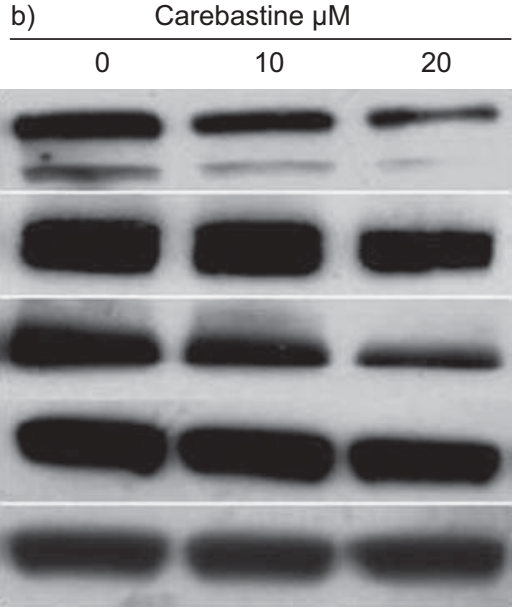

$\mathrm{kDa}$

200

$230 / 210$

60

60

42

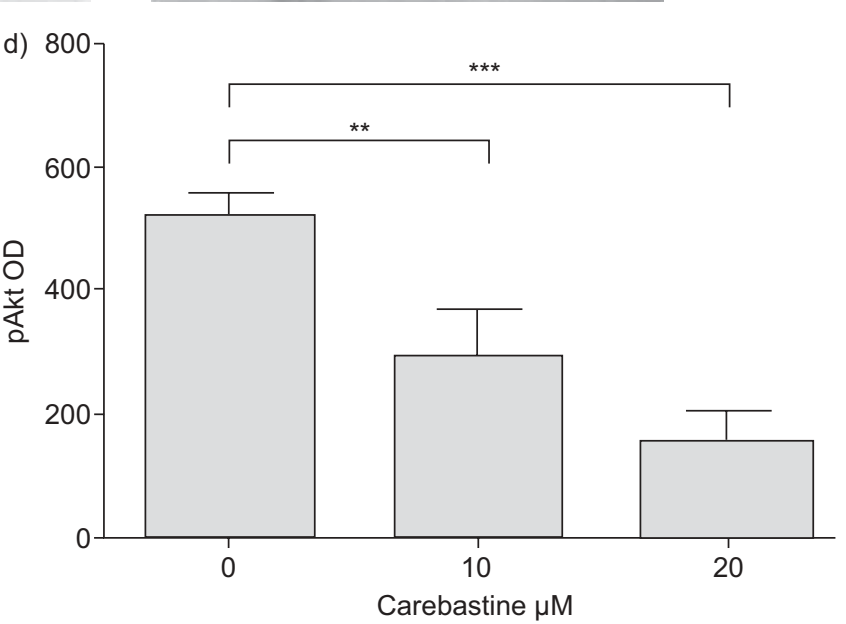

FIGURE 4. Western blotting demonstrating the effect of carebastine on phosphorylation of vascular endothelial growth factor (VEGF) receptor (VEGFR)-2 and Akt kinase (Akt). a) Time-course of phosphorylation of VEGFR-2 (pVEGFR-2) and Akt (pAkt) in response to carebastine. Human umbilical vein endothelial cells were synchronised in serum-free medium for 18-20 h and then treated with $\mathrm{VEGF}_{165}$ and $10 \mu \mathrm{M}$ carebastine for $24 \mathrm{~h}$. Samples were subsequently analysed on a separate blot using antibodies against nonphosphorylated (total) VEGFR-2 and Akt in order to confirm equal loading in each lane. b) Dose-dependence of the inhibitory effect on VEGFR-2 and Akt phosphorylation of 10 and $20 \mu \mathrm{M}$ carebastine. The lanes shown are representative of five independent experiments. Densitometric analysis of: c) pVEGFR-2; and d) pAkt. The analysis was performed with the Kodak Molecular Imaging Software (Eastman Kodak Co., Rochester, NY, USA) and is presented using mean \pm SD arbitrary optical density (OD) units. ${ }^{* *}: p<0.01 ;{ }^{* *}: \mathrm{p}<0.001 ;{ }^{*}: \mathrm{p}<0.03$ (one-way ANOVA). 
a)

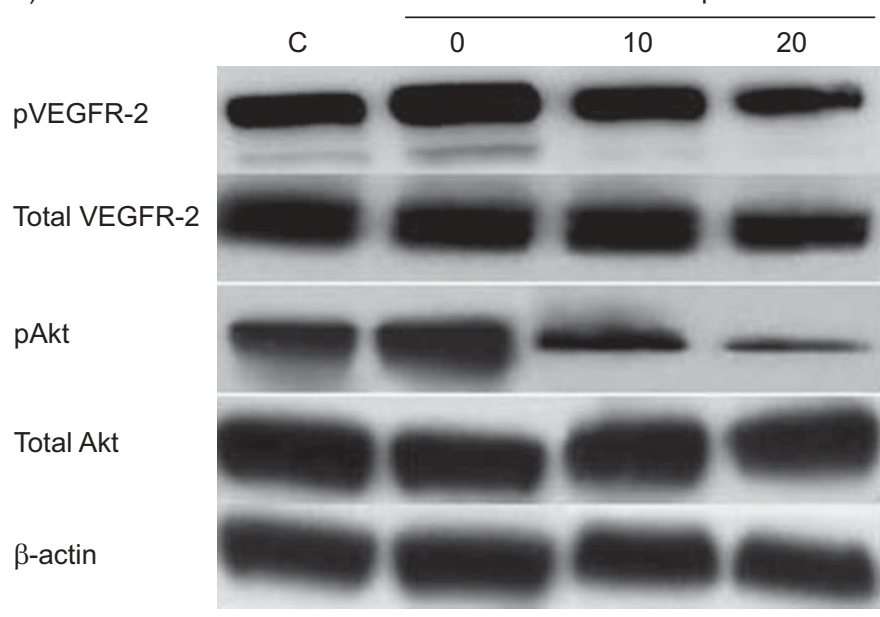

c)

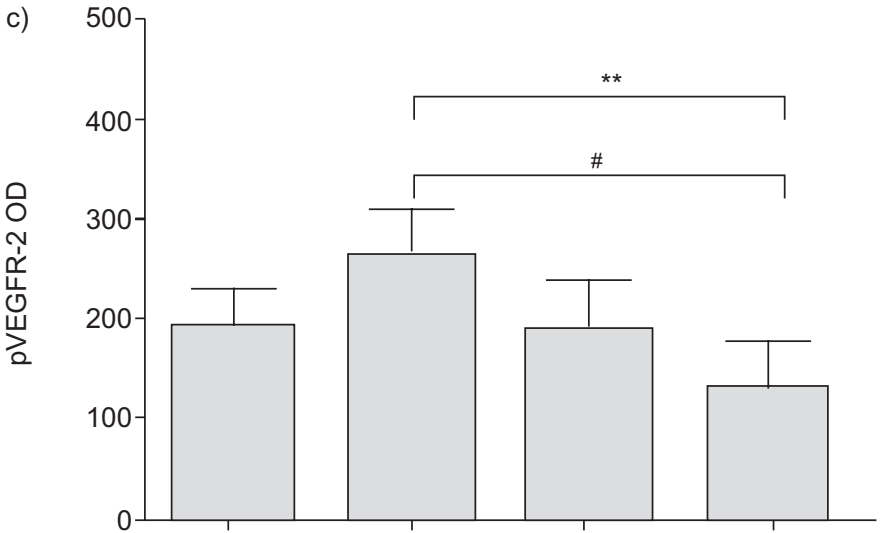

e)

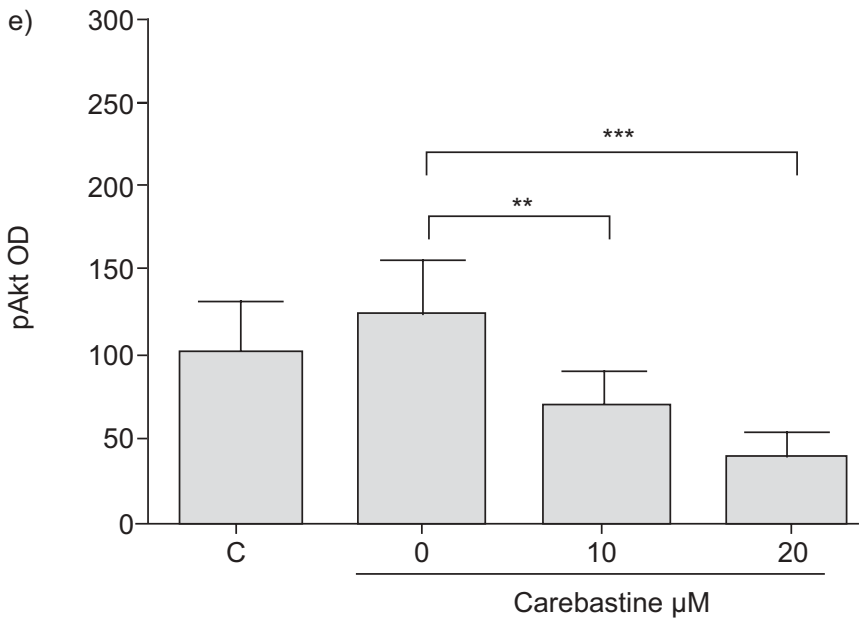

b)

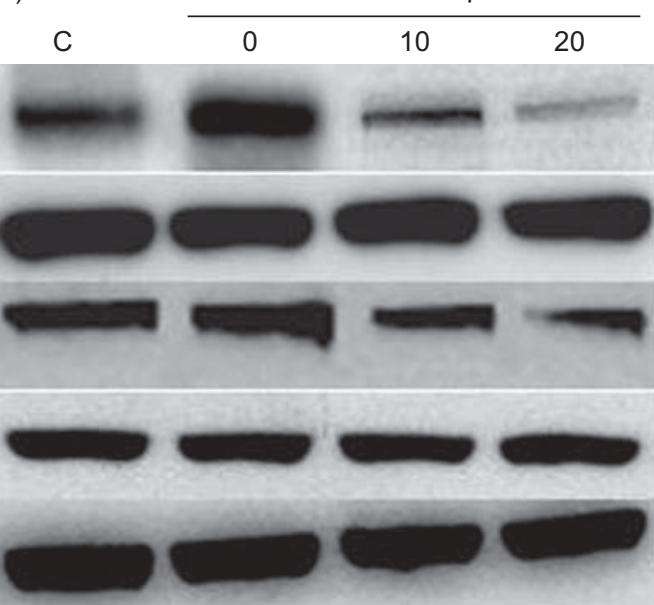

$\mathrm{kDa}$

200

$230 / 210$

60

60

42

d)

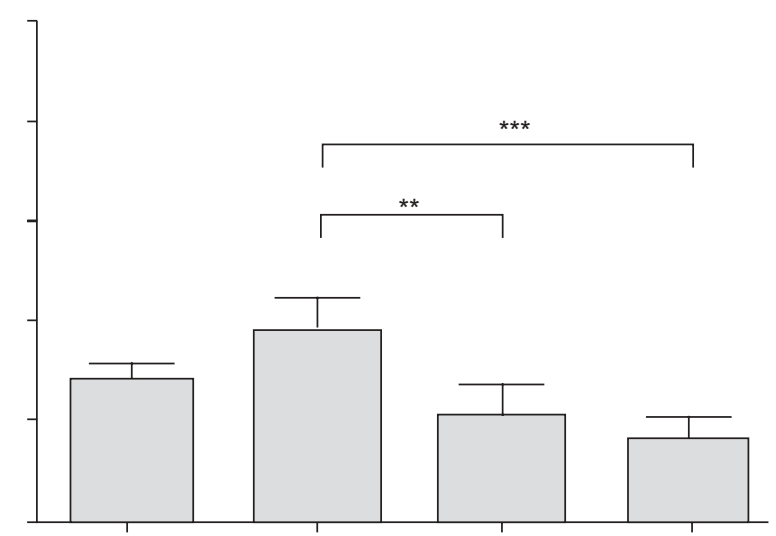

f)

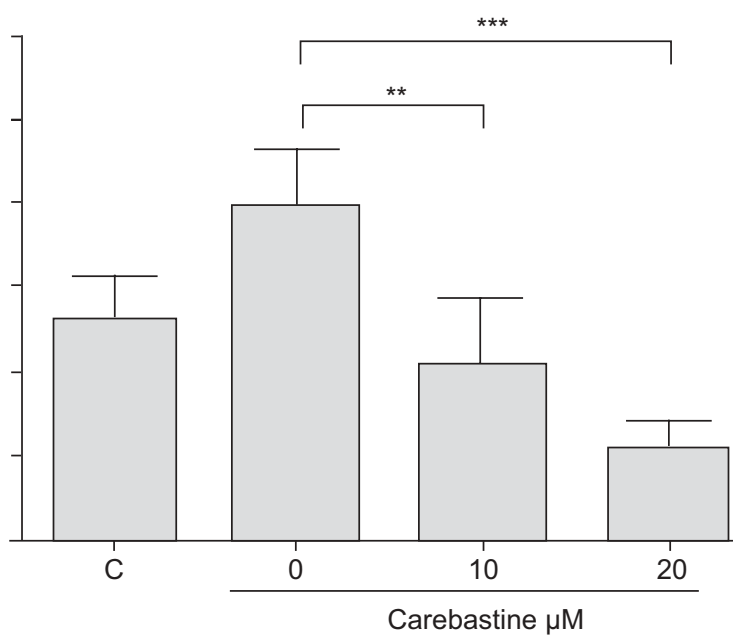

FIGURE 5. Western blotting demonstrating the effect of carebastine on vascular endothelial growth factor (VEGF) receptor (VEGFR)-2 and Akt kinase (Akt) phosphorylation mediated by histamine $\mathrm{H}_{1}$ receptor. Increased VEGFR-2 and Akt phosphorylation induced by $30 \mu \mathrm{M}$ histamine, and inhibition of $\mathrm{H}_{1}$ receptor-induced phosporylation by 10 and $20 \mu \mathrm{M}$ carebastine in: a) human umbilical vein endothelial cells (HUVECs); and b) human pulmonary artery endothelial cells (HPAECs). Cells were synchronised in serum-free medium for 18-20 h and then treated with VEGF $_{165}$ alone (control (C)) or in combination with $30 \mu \mathrm{M}$ histamine alone or added with 10 or $20 \mu \mathrm{M}$ carebastine. Samples were subsequently analysed on a separate blot using antibodies against nonphosphorylated (total) VEGFR-2 and Akt in order to confirm equal loading in each lane. The lanes shown are representative of five independent experiments. Densitometric analysis of: c, d) pVEGFR-2; and e, f) pAkt in: c, e) HUVECs; and d, f) HPAECs. The analysis was performed with the Kodak Molecular Imaging Software (Eastman Kodak Co., Rochester, NY, USA) and is presented using mean \pm SD arbitrary optical density (OD) units. **: $p<0.01$; ${ }^{* \star}: \mathrm{p}<0.001 ;{ }^{*}: \mathrm{p}<0.03$ (one-way ANOVA). 

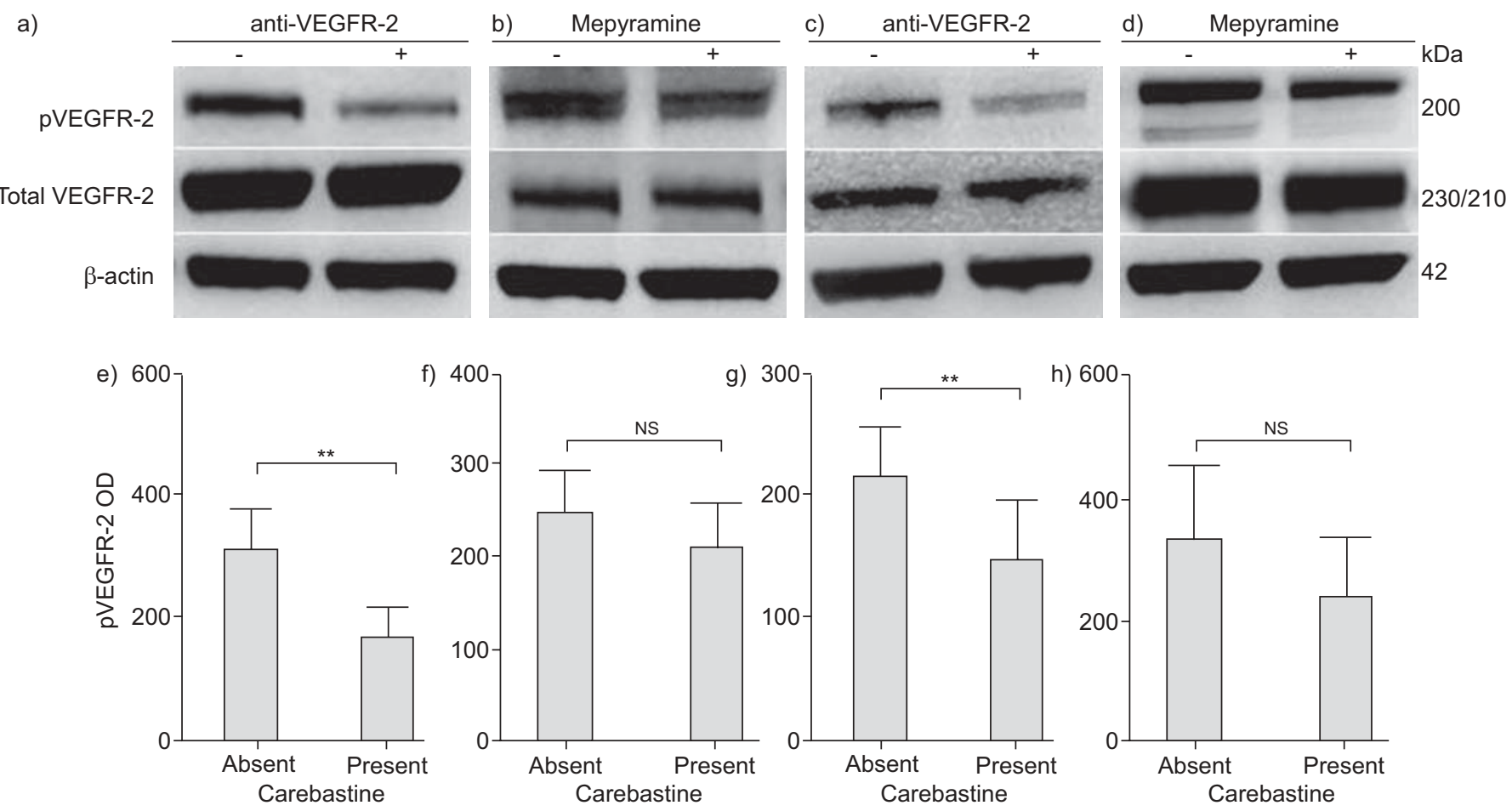

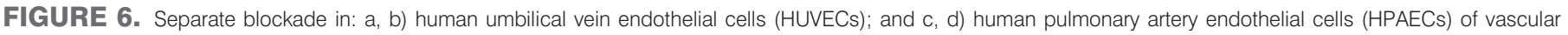

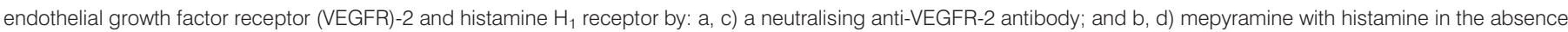

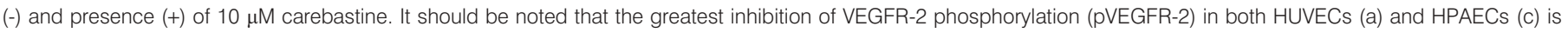

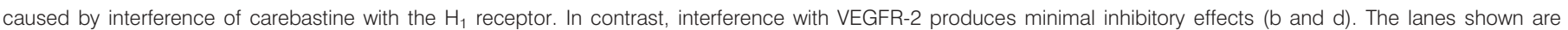

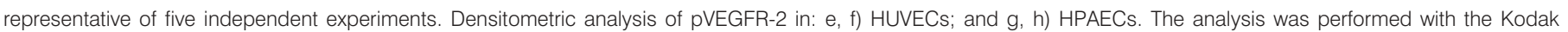

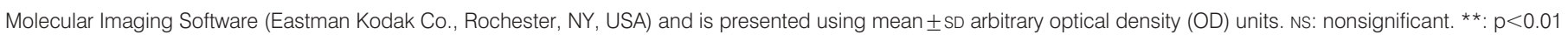
(one-way ANOVA).

the downstream Akt, suggesting that the inhibition of the VEGFR-2 and Akt pathways is mediated through blocking $\mathrm{H}_{1}$ receptor activity. In separate inhibition experiments involving VEGFR-2 and $\mathrm{H}_{1}$ receptor, it was found that carebastine inhibited VEGFR-2 phosphorylation mostly via interference with the $\mathrm{H}_{1}$ receptor. Thus it may well be that signalling downstream of the $\mathrm{H}_{1}$ receptor and VEGFR-2 are closely interrelated, perhaps via Akt. In addition, it was found that carebastine inhibited, albeit to a lesser extent, VEGFR-2 phosphorylation following $\mathrm{H}_{1}$ receptor blockade. Thus an interference of carebastine with VEGFR-2, perhaps via aspecific mechanisms, can be hypothesised. Overall, the data suggest that the anti-angiogenic activity of carebastine is mediated through both a $\mathrm{H}_{1}$ receptor-dependent and -independent mechanism, though the former is prevalent.

In addition, it is conceivable to hypothesise that the $\mathrm{H}_{1}$ receptor signalling affected by carebastine activates protein kinase (PK) C instead of PKA, since a PKC activator (phorbol-12-myristate13-acetate) enhances $\mathrm{H}_{1}$ receptor activation, whereas an activator of PKA does not [29]. Furthermore, histamine-induced activation of the $\mathrm{H}_{1}$ receptor is fully suppressed by the PKC inhibitor Ro-31-8220 [30]. Downregulation of NF- $\kappa B$ may be also involved in the mechanism of action of carebastine. Indeed, low concentrations of $\mathrm{H}_{1}$ receptor antagonists (cetirizine and azelastine) have been demonstrated to downregulate
NF- $\kappa$ B expression in parallel to inhibition of pro-inflammatory cytokines [7].

VEGF seems to be the most important factor involved in the angiogenic processes taking place in allergic rhinitis [9] and asthma [10], and plays an important role in disease development and persistence. Indeed, both VEGF and expression of its receptor VEGFR-2 are increased in the nasal mucosa of patients with allergic rhinitis compared to nonallergic controls [12]. Moreover, in the bronchial mucosa of asthmatic patients, the number of VEGF-positive cells is significantly increased and correlates with the vessel counts and vascular area, and expression of VEGFR-1 and VEGFR-2 inversely correlates with airway function [16-20, 23]. VEGF levels in BALF were increased in asthma in direct proportion to vascularity [19, 20]. In addition, through its permeability activity, VEGF contributes to oedema since it favours microvascular leakage. VEGF is secreted by several inflammatory cells, such as macrophages, mast cells and eosinophils, which intervene in the composition of the inflammatory infiltrate in allergic rhinitis and asthma [12,31-34]. It has been demonstrated [35] that airway smooth muscle cells from patients with mild or moderate asthma, but not from healthy (control) subjects, promote angiogenesis in vitro. This pro-angiogenic capacity resides in elevated VEGF release and suggests that airway smooth muscle cells regulate airway neovascularisation in asthma. 
In view of the present findings, new clinical strategies aimed at downregulation of VEGF and its receptors and signalling might be of benefit in the treatment of allergic diseases. Tentatively, the present data providing the first evidence of the anti-angiogenic activity of ebastine suggest its potential use as an anti-angiogenic molecule, besides its antihistamine activity in the treatment of allergic diseases in which angiogenesis occurs.

\section{SUPPORT STATEMENT}

This study was supported by the Italian Association for Cancer Research (Milan, Italy), and the Ministry of Education, University and Research (Projects of National Interest 2007) and the Ministry of Health (Oncology Project 2006) (both Rome, Italy). The supporting institutions played no role in gathering, analysing or interpreting the data.

\section{STATEMENT OF INTEREST}

Statements of interest for all authors, and for the study itself can be found at www.erj.ersjournals.com $/ \mathrm{misc} /$ statements.dtl

\section{REFERENCES}

1 Hayashi S, Hashimoto S. Anti-inflammatory actions of new antihistamines. Clin Exp Allergy 1999; 29: 1593-1596.

2 Leurs R, Church MK, Tagliatela M. $\mathrm{H}_{1}$-antihistamines: inverse agonism, anti-inflammatory actions and cardiac effects. Clin Exp Allergy 2002; 32: 489-498.

3 Aoki Y, Qiu D, Zhao GH, et al. Leukotriene $\mathrm{B}_{4}$ mediates histamine induction of NF- $\mathrm{\kappa B}$ and IL-8 in human bronchial epithelial cells. Am J Physiol 1998; 274: L1030-L1039.

4 Megson AC, Walker EM, Hill SJ. Role of protein kinase $C_{\alpha}$ in signaling from the histamine $\mathrm{H}_{1}$ receptor to the nucleus. Mol Pharmacol 2001; 59: 1012-1021.

5 Arnold R, Rihoux J, Konig WQ. Cetirizine counter-regulates interleukin-8 release from human epithelial cells (A549). Clin Exp Allergy 1999; 29: 1681-1691.

6 Papi A, Papadopoulos NG, Stanciu LA, et al. Effect of desloratadine and loratadine on rhinovirus-induced intercellular adhesion molecule 1 upregulation and promoter activation in respiratory epithelial cells. J Allergy Clin Immunol 2001; 108: 221-228.

7 Yoneda K, Yamamoto T, Ueta E, et al. Suppression by azelastine hydrochloride of NF-kB activation involved in generation of cytokines and nitric oxide. Jpn J Pharmacol 1997; 73: 145-153.

8 Nori M, Iwata S, Munakata Y, et al. Ebastine inhibits $\mathrm{T}$ cell migration, production of Th2-type cytokines and proinflammatory cytokines. Clin Exp Allergy 2003; 33: 1544-1554.

9 McDonald DM. Imaging of angiogenesis in inflammation and cancer: lessons for novel treatment of allergic rhinitis. Clin Exp Allergy Reviews 2007; 7: 11-18.

10 Walters EH, Reid D, Soltani A, et al. Angiogenesis: a potentially critical part of remodelling in chronic airway diseases? Pharmacol Ther 2008; 118: 128-137.

11 Wilson J. The bronchial microcirculation in asthma. Clin Exp Allergy 2000; 30: 51-53.

12 Yuksel H, Kose C, Yilmaz O, et al. Increased expression of tissue vascular endothelial growth factor and foetal liver kinase-1 receptor in seasonal allergic rhinitis and relevance to asthma component. Clin Exp Allergy 2007; 37: 1183-1188.

13 Kuwano K, Bosken $\mathrm{CH}$, Paré PD, et al. Small airways dimensions in asthma and in chronic obstructive pulmonary disease. Am Rev Respir Dis 1993; 148: 1220-1225.

14 Li X, Wilson JW. Increased vascularity of the bronchial mucosa in mild asthma. Am J Respir Crit Care Med 1997; 156: 229-233.
15 Salvato G. Quantitative and morphological analysis of the vascular bed in bronchial biopsy specimens from asthmatic and nonasthmatic subjects. Thorax 2001; 56: 902-906.

16 Hoshino M, Takahashi M, Aoike N. Expression of vascular endothelial growth factor, basic fibroblast growth factor, and angiogenin immunoreactivity in asthmatic airways and its relationship to angiogenesis. J Allergy Clin Immunol 2001; 107: 295-301.

17 Orsida BE, Li X, Hickley B, et al. Vascularity in asthmatic airways: relation to inhaled steroid dose. Thorax 1999; 54: 289-295.

18 Hashimoto M, Tanaka H, Abe S. Quantitative analysis of bronchial wall vascularity in the medium and small airways of patients with asthma and COPD. Chest 2005; 127: 965-972.

19 Feltis BN, Wignarajah D, Zheng L, et al. Increased vascular endothelial growth factor and receptors: relation to angiogenesis in asthma. Am J Respir Crit Care Med 2006; 173: 1201-1207.

20 Feltis BN, Wignarajah D, Reid DW, et al. Effects of inhaled fluticasone on angiogenesis and vascular endothelial growth factor in asthma. Thorax 2007; 62: 314-319.

21 Redington AE, Roche WR, Madden J, et al. Basic fibroblast growth factor in asthma: measurement in broncholaveolar lavage fluid basally and following allergen challenge. J Allergy Clin Immunol 2001; 107: 384-387.

22 Simcock DE, Kanabar V, Clarke GW, et al. Proangiogenic activity in bronchoalveolar lavage fluid from patients with asthma. Am J Respir Crit Care Med 2007; 176: 146-153.

23 Lee CG, Link H, Baluk P, et al. Vascular endothelial growth factor (VEGF) induces remodelling and enhances $\mathrm{T}_{\mathrm{H}} 2$-mediated sensitization and inflammation in the lung. Nat Med 2004; 10: 1095-1103.

24 Vacca A, Ribatti D, Presta M, et al. Bone marrow neovascularization, plasma cell angiogenic potential, and matrix metalloproteinase-2 secretion parallel progression of human multiple myeloma. Blood 1999; 93: 3064-3073.

25 Kueng W, Silber E, Eppenberger U. Quantification of cells cultured on 96-well plates. Anal Biochem 1989; 182: 16-19.

26 Scavelli C, Di Pietro G, Cirulli T, et al. Zoledronic acid impacts over-angiogenic phenotype of endothelial cells in patients with multiple myeloma. Mol Cancer Ther 2007; 6: 3256-3262.

27 Guidolin D, Vacca A, Nussdorfer GG, et al. A new image analysis method based on topological and fractal parameters to evaluate the angiostatic activity of docetaxel by using the Matrigel assay in vitro. Microvasc Res 2004; 67: 117-124.

28 Ribatti D, Nico B, Vacca A, et al. The gelatin sponge-chorioallantoic membrane assay. Nat Protoc 2006; 1: 85-91.

29 Das AK, Yoshimura S, Mishima R, et al. Stimulation of histamine $\mathrm{H}_{1}$ receptor up-regulates histamine $\mathrm{H}_{1}$ receptor itself through activation of receptor gene transcription. J Pharmacol Sci 2007; 103: 374-382.

30 Miyoshi K, Kawakami N, Das AK, et al. Heterologous upregulation of the histamine $\mathrm{H}_{1}$ receptor by $\mathrm{M}_{3}$ muscarinic receptor-mediated activation of $\mathrm{H}_{1}$-receptor gene transcription. J Pharm Pharmacol 2007; 59: 843-848.

31 Puxeddu I, Alian A, Piliponski AM, et al. Human peripheral blood eosinophils induce angiogenesis. Int J Biochem Cell Biol 2005; 37: 628-636.

32 Puxeddu I, Ribatti D, Crivellato E, et al. Mast cells and eosinophils: a novel link between inflammation and angiogenesis in allergic diseases. J Allergy Clin Immunol 2005; 116: 531-536.

33 Chetta A, Zanini A, Foresi A, et al. Vascular endothelial growth factor up-regulation and bronchial wall remodelling in asthma. Clin Exp Allergy 2005; 35: 1437-1442.

34 Asai K, Kanazawa H, Otani K, et al. Imbalance between vascular endothelial growth factor and endostatin levels in induced sputum from asthmatic subjects. J Allergy Clin Immunol 2002; 110: 571-575.

35 Simcock DE, Kanabar V, Clarke GW, et al. Induction of angiogenesis by airway smooth muscle from patients with asthma. Am J Respir Crit Care Med 2008; 178: 460-468. 